\title{
THE AESTHETICS OF SHADOW
}





\section{THE AESTHETICS OF SHADOW}

Lighting and Japanese Cinema

\section{DA IS UKE MIYAO}

Duke University Press

Durham and London 2013 
(C) 2013 Duke University Press

All rights reserved

Printed in the United States of America on acid-free paper @ Designed by Heather Hensley

Typeset in Arno Pro by Tseng Information Systems, Inc.

Library of Congress Cataloging-in-Publication Data appear on the last printed page of this book. 
